FACTA UNIVERSITATIS

Series: Economics and Organization Vol. 18, № 2, 2021, pp. 187 - 201

https://doi.org/10.22190/FUEO210319013A

Original Scientific Paper

\title{
OWNERSHIP STRUCTURE AND FINANCIAL PERFORMANCE OF MANUFACTURING FIRMS IN SUB-SAHARAN AFRICA
}

\author{
UDC 339
}

\section{Mayowa Gabriel Ajao, Jude Osazuwa Ejokehuma}

Department of Banking and Finance, Faculty of Management Sciences

University of Benin, Benin City, Nigeria

\begin{abstract}
This study investigates the effect of ownership structure on the financial performance of listed manufacturing firms in three Sub-Saharan Africa countries (Nigeria, Kenya and South-Africa) based on the critical mass indices of their respective bourse. Relevant data from the financial reports of sampled firms were analyzed using the co-integration test and the system-GMM for a period 2010-2019 using Return on Asset, and Tobin- $Q$ as dependent variables while government ownership, block ownership and institutional ownership concentrations were explanatory variables. The empirical results revealed that all the explanatory variables have significant effect on the performance indicators (ROA, TOBIN $Q$ ). The result of robustness checks also revealed that both government and institutional ownership concentrations have predominately negative effect on financial performance for the respective countries while block ownership concentration is largely positive for most of the manufacturing firms. The study recommends that policy makers should create favorable policies to encourage balanced investment from all categories of investors and ensure only few owners who have the wherewithal to diversify and attract skills and competencies to improve firm performance. Government should also retain some ownership in foreign and local firms to enhance shareholders' confidence.
\end{abstract}

Key words: Ownership structure, manufacturing Firms, Performance, GMM

JEL Classification: G32, L25, L60

Received March 19, 2021 / Revised May 10, 2021 / Accepted May 26, 2021

Corresponding author: Mayowa Gabriel Ajao

Department of Banking and Finance, Faculty of Management Sciences University of Benin, Benin City, Nigeria

E-mail: ajao.mayowa@uniben.edu 


\section{INTRODUCTION}

The modern argument about the owner-manager relationship was initiated by Berle and Means (1932) and proposed an indirect association among the diffusion of equity holdings and company's profitability. They suggested that a complex diffuse rights break down the relationship among management and ownership, in furtherance optimization of income is hence not certain. The fewer equities each equity holder holds the less authority he or she can exert on the skilled agent. After been torpid for years, the argument was engaged by Monsen, Chiu and Cooley (1968) who examined the influence of the parting of rights from control on the value of big companies. They discovered that principal managed companies were more lucrative than companies managed by agents. The recent past has witnessed significant changes in ownership concentration with respect to ownership structure mechanism, due to breakdown of reputable firms like Enron and WorldCom in U.S.A. The trend was replicated across the globe as evidenced by collapse of Parmalat Company in Europe, Chuo Aoyama in Asia, $\mathrm{JCl}$ and Randgold in South Africa, Skye bank in Nigeria, Uchumi, Imperial bank and Chase bank in Kenya (Ongore \& K'Obonyo,2011). Attracting keen scholarly consideration to the relevance of the various ownership structure influencing profitability of firms, the link between ownership structure and performance of firms has led to a serious concern to corporate investors leading to a significant consideration in the larger scope of modern finance and amongst various stakeholders.

Jiang (2015) recommends that since ownership structure is an important component in present corporate governance mechanism, there should be a departure of firm ownership from firm management. Berghe and Levrau (2007) note that ownership structure is primarily the driving force mutually for investing public and creditors because owners of a firm have economic relations with a company and influence the types of decisions taken by the firm to reduce the exposure to financial risk and improve financial performance. This is because ownership concentration has the capacity of putting decent governance structures in place to enhance firm's ability to attract external funding (Trien \& Chizema, 2011). Villalonga and Amit (2006) suggest a direct relationship between rights acquisition and company's profitability because board members elected by the owners' function as the intermediary between them and their managers. The board is saddled with four main obligations such as: leadership obligation; stewardship obligation; monitoring obligation; and reporting back to owners which has a direct bearing on financial performance. Jensen (1989) and Lins (2002) argue that the effectiveness of the board helps to alleviate the agency conflicts whenever business decisions and choices of principals are at variance through controlling and monitoring the managerial actions. The internal influence imposed by the board reinforces the external function of the markets in monitoring and controlling managers (Jensen, 1989). According to Brown (2004), the constraints imposed by the board to the management makes them to be extra vigilant as they exercise their discretion to avoid managerial ineptitude, which leads to weak financial performance and wears away potential investors confidence. Mugobo et al (2016) present evidence that in advanced economies, ownership structure is largely dispersed while the ownership structure in developing nations is highly concentrated. They observed that largely absorption of ownership structure is a product of porous legal system in developing nations, which exposes minority shareholders' interest to financial risk.

A majority of quoted firms in Sub-Sahara Africa bourses have mixed forms of ownership, the main forms of ownership are; government, block, institutional, foreign, 
and managerial ownership that impacts the profitability of the firms either positively or negatively high ownership concentration stands out as a common characteristic of listed firms at the respective bourses. This consequently empowers controlling shareholders to impose power by selectively choosing to undertake activities with an intent of obtaining personal gain. This comes at the expense of marginal shareholders, (Mudi, 2017; Adebiyi and Kajola, 2011). Based on the researchers' understanding, only the work of Munisi and Randy (2013) recently employed the dynamic-GMM to investigate the effect of concentrated rights on the performance of companies in Sub-Saharan African countries. This study however built on this previous research to focus on the impact of ownership structure on the profitability of manufacturing companies in Sub-Saharan African nations for a period of 10 years (2010 to 2019). The justification for this time frame is based on economic globalization regarded as one of the strong motives after the major financial modifications in various SubSaharan African Countries, an era of global competitiveness among manufacturing firms in the region. The geographical scope selected for this study are Nigeria, Kenya, and SouthAfrica - the reason for this is centered on the fact that the Nigeria bourse in terms of market capitalization is the third biggest bourse in the continent with a total market capitalization of over 13 trillion Naira (Nigeria Stock Exchange, 2018). The Johannesburg bourse is presently rated the 19th biggest stock exchange in the globe by market capitalization and the biggest bourse in Africa (JSE.CO.Za, 2018). Nairobi Stock Exchange has grown to become the continent's fourth-largest exchange by trading volume and fiftieth largest by market capitalization as a ratio of GDP (Nairobi Stock Exchange, 2018).

The rationale for this study is to determine the effect of different ownership structures (government, block and institutional) on two performance measurement variables (return on assets and Tobin q) with emphasis on quoted manufacturing firms of three selected SSA economies. The data analysis of the study was on the assessment of changes in the financial performance arising from adoption of different ownership structures. Besides, this study adopts the system Generalized Method of Moment (GMM) technique (an active panel data models which pools moment settings for the differenced equation with moments settings for the models in ranks) as a departure from the multiple regression technique commonly found in extant literature. The uniqueness of this study also focus on aggregate analysis of three SSA countries as different from previous studies with emphasis on individual country analysis. The comparative analysis of the two performance variables (ROA and Tobin Q) to determine the best and superior performance measure of manufacturing firms is another significant contribution of this study to extant literature.

The remainder of this study is organized as follows. Section two reviews the relevant literature and previous studies related to this study. Section three describes the methodologies adopted for the studies including the model formulation and data analysis techniques. In section four, the main empirical test results were presented and interpreted while section five summarizes the empirical findings and concludes the study.

\section{LITERATURE REVIEW}

\subsection{Ownership Structure}

Ownership structure is a vital internal corporate governance component where principals can scrutinize and oversee the operations of the company to safeguard their investment, (Madhani, 2016). It signifies the proportion of equity owned by single shareholder and huge 
block shareholders (individuals that hold minimum 5\% of shares within the firm). According to Maina (2014), Benjamin \& Dirk (2015) and Nahila \& Amarjeet (2016) concentrated ownership is defined by the distribution of stakes in relation to the distinctiveness of the equity holders and its classification within company's governance structure that has impacted firm financial performance for several decades. Jiang (2015) recommends that since rights concentration is an important component in present company's governance structure, there should be a departure of firm ownership from firm management. Three basic types of ownership concentration have been identified in the extant literature. Block ownership concentration: This is when a proportion of a firm's equity is acquired by major equity holders. Government ownership concentration: A situation in which large proportion of equities and controlling shares of a firm is owned by government. This ownership structure is enhanced through political appointment of the managers. Institutional ownership concentration: These are organizations that own huge sums of resources to invest and they do commit huge amount of funds into a firm's equity e.g. pension reserves, insurance firms, mutual funds and combined performance is termed as the neutrality assumption.

\subsection{Relationship between ownership concentration and performance of firms: Empirical Review}

Ownership structure can be along two scopes: rights acquisition and ownership mix. Right acquisition implies stakes of the biggest shareholder while ownership mix is the allotment of company's equity with reference to the distinctiveness of the biggest equity holders. Gonzalez and Molina (2010) noted that superior rights-acquisition enhances company's profitability and concluded that rights structure is the essential factor that impacts firm's ownership and supervises resources distribution, and it has a huge effect on firm performance. Though according to Friedman (1953), Saunders et al (2000), firms operate uniformly well under various rights settings since competition in the market will reduce all ineffective forms in the long run. Therefore, there is no influence of rights structure on profitability; an ideal rights structure and profitability depend on the environment.

Malik (2011) conducted a study on the influence of rights concentration on risk and growth in USA non-financial companies with a sample size of $187 \mathrm{firms}$, the variance in equity/profit ratio was used as an indicator of risk while its dependency was tested on ownership concentration. The findings of the study showed an insignificant positive correlation between firms coordinated by managers as opposed to firms controlled by owners and in addition a high variance in profit/equity. Garcia and Sanchez (2011) examined the correlation among ownership structure and profitability of companies by employing a nonbalanced panel consisting of 76 firms in the Spanish bourse between 1999 and 2002, the study employed piecewise OLS and 2SLS regression with random effects. The outcome of the study specified the presence of a quadratic correlation among Tobin Q and large shareholdings.

Santamaria and Azofra (2011) carried out an examination on the association for ownership structure and corporate profitability of eighty banks in Spain. Employing panel data collected between 1996 and 2004, analyzed by Generalized Methods of Moments, the study found a point of departure for voting rights and the larger shareholders cash flow for smaller firms by ROA. The study was well conducted with reference to financial ratios determining bank performance.

Similarly, Adebiyi and Kajola (2011) examined the correlation between rights structure and firm performance in Nigeria, using a sample of thirty listed companies from 2001 to 2008, 
using pooled OLS, the outcome being a significant negative association among rights structure and performance of the company. Wanjiku (2014) investigated the effect of ownership structure on profitability of sixty-three quoted companies at the NSE between 2010 to 2014. The researcher employed both cross-sectional and descriptive survey method to allow for evaluation of the results of the research. The study found that ownership concentration alleviates conflicting interest between managers and owners thus promoting improved monitoring.

Mutisya (2015) examined the correlation among investors shareholding and firm profitability by adopting a descriptive research design of sixty-four listed companies on the NSE from 2010 to 2014. Multiple regression analysis results reported a weak positive correlation as the outcome of the study. Mugobo et al. (2016) investigated the influence of company's control through ownership structures; rights acquisition, state ownership and administrative ownership on firm profitability. A multiple regression analysis was used on sampled data gathered over ten years from 2001 to 2010 for eighty south Africa firms with ROA as indicator for profitability. Findings revealed a positive relationship between rights acquisition and profitability of the firm. Mudi (2017) investigated the influence of rights structure on profitability of firms quoted on the NSE. It employed descriptive survey and longitudinal research design of fifty-two companies quoted on the NSE between 2011 and 2016. The research found out that rights acquisition has a huge influence on firm profitability.

Paniagua, Rivelles \& Sapena (2018) studied firms' performance with different ownership structure of US firms using generalized non-linear equation technique. The study found that ownership structure has negative relationship with profitability ratio. Kao, Hodgkinson \& Jaafar (2018) used data of Taiwan listed firms to study the relationship between ownership structure and firm value using panel estimation and 2SLS. The study found that ownership structures are positively related to firm value. In the same vein, Alabdullah (2018) studied the relationship between ownership structures and firm performance of Jordan non-financial firms listed on Amman stock exchange. The multiple regression results showed that managerial ownership has a positive impact performance but no significant impact of foreign ownership on performance.

Sadiq, Othman \& Ooi (2019) studied the relationship between managerial ownership and firm performance of firms listed on Bursa Malaysia with the aid of single equation model. The study found limited evidence showing the non-linear relationship between firm performance and managerial ownership. Feldman, Amit \& Villalonga (2019) also explored the non-linear relationship between managerial ownership and firm profitability of 350 firms using linear regression. They found a positive relationship between ownership structure and Tobin's $\mathrm{Q}$ for board ownership of between 0 and 5\% and negative relationship for board ownership of between 5 and 25\%. Dakhlallh, Rashid, Abdullah \& Dakhlallh (2019) used pool mean estimates to study the effect of ownership structure on firm performance of 180 selected Jordan firms. The empirical results showed that ownership structure has a significant effect on the performance of the selected firms.

Established on the extensive and robust empirical review above, it is clear that ownership acquisition and firm performance have been largely explored from diverse perspectives and methodologies. These methods are largely part of conventional techniques regrettably, these approaches have their drawbacks and demerits in that they are sensitive to outliers, focuses on the mean of the dependent variables, the test statistics might be unreliable when data is not normally distributed. This study however adopts the system Generalized 
Method of Moment (GMM) technique. Accordingly, the system GMM technique is an active panel data model which pools moment settings for the differenced equation with moments settings for the models in ranks which can make assessment most effective. This technique supports the premise that the first difference of instrumental parameters for rank parameters is not connected with unobserved specific effects, that is an indication that the difference of scheduled parameters can be used as a tool for rank equations.

\section{Methodology}

The study adopts the causal research design to investigate the impact of ownership concentration on firm performance of selected manufacturing firms in Sub-Sahara Africa countries. All quoted manufacturing firms listed on the Stock Exchanges of the three selected Sub-Sahara Africa countries (Nigeria, Kenya and South Africa) constitute the population of this study while a sample of one hundred manufacturing firms were purposively selected from each country based on data accessibility and the requisite information for the period (2010-2019) under study. The relevant data for this study were obtained from the various audited financial statements of sampled manufacturing firms with the system Generalized Method of Moment (GMM) technique as the main analytical technique for determining the effect of different ownership structure on two different performance measurement variables.

\subsection{Model Specification}

This study employs two specific models such as book-keeping base performance and the market base performance indicators. The model incorporating measures (ROA and Tobin Q) and decomposing ownership concentration into various variables (government ownership, block ownership, institutional ownership) to suit the study is stated in a functional form as follow:

$$
\begin{gathered}
R O A=f(G O W N, B L O W N, I N O W N, \text { ASSETS, AGE }) \\
\text { TOBINQ }=f(G O W N, B L O W N, I N O W N, \text { ASSETS, AGE })
\end{gathered}
$$

The econometric form of the models is stated below as:

$$
\begin{aligned}
& R O A_{i t}=\beta_{0}+\beta_{1} \text { GOWN }_{i t}+\beta_{2} \text { BLOWNi }_{t}+\beta_{3} \text { INOWN }_{i t}+\beta_{4} \text { ASSETS }_{i t}+\beta_{5} A G E_{i t}+U_{t} \\
& \text { TOBINQ }_{i t}=\alpha_{0}+\alpha_{1} G O W N_{i t}+\alpha_{2} \text { BLOWN }_{i t}+\alpha_{3} I_{N O W N}+\alpha_{4} \text { ASSETS }_{i t}+\alpha_{5} A G E+U_{t}
\end{aligned}
$$

Where:

GOWN = Government Ownership; BLOWN = Block Ownership

INOWN = Institutional Ownership; ASSETS = Total Asset

$\mathrm{AGE}=$ Age of Firm; ROA = Return on Assets, TOBIN Q = Tobin Q

Where i represent companies in all sample and t represents the scope or period of study.

$\beta_{0}$ to $\beta_{5}$ are coefficients of the variables to be appraised and $U_{t}$ is the error term. 
Hence the GMM model specification is:

$$
\begin{aligned}
& R O A_{i t_{t-1}}=\beta_{t}+\sum_{j=1}^{m} \beta_{j} R O A_{t-1}+\sum_{j=1}^{m} \beta_{j} G O W N+\sum_{j=1}^{m} \beta_{j} B L O W N+\sum_{j=1}^{m} \beta_{j} I N O W N+ \\
& \sum_{j=1}^{m} \beta_{j} A S S E T S+\sum_{j=1}^{m} \beta_{j} A G E+\varepsilon_{i t} \\
& \text { TOBIN } Q_{i t_{t-1}}=\alpha_{t}+\sum_{j=1}^{m} \alpha_{j} R O A_{t-1}+\sum_{j=1}^{m} \alpha_{j} G O W N+\sum_{j=1}^{m} \alpha_{j} B L O W N+\sum_{j=1}^{m} \alpha_{j} I N O W N+ \\
& \sum_{j=1}^{m} \alpha_{j} A S S E T S+\sum_{j=1}^{m} \alpha_{j} A G E+\varepsilon_{i t}
\end{aligned}
$$

\begin{tabular}{|c|c|c|c|}
\hline Variable & $\begin{array}{l}\text { Type of } \\
\text { variable }\end{array}$ & Definition and measurement & $\begin{array}{c}\text { A priori } \\
\text { Expectation }\end{array}$ \\
\hline Return on Asset (ROA) & Dependent & ROA $=$ Profit after tax/Total Assets & \\
\hline Tobin's Q (TQ) & , & $\begin{array}{l}\text { Total market value of equity-total liability } \\
\text { /Total Asset }\end{array}$ & \\
\hline Institutional Ownership & Independent & The sum of $5 \%$ corporate ownership & $(+)$ \\
\hline Block Ownership & , & The sum of all $5 \%$ major share ownership & $(+)$ \\
\hline Government Ownership & " & $\begin{array}{l}\text { The sum of all } 5 \% \text { and above government } \\
\text { shares holding }\end{array}$ & $(+)$ \\
\hline Firm Age & ," & $\begin{array}{l}\text { The number of years from the day the firm } \\
\text { was established till } 2017\end{array}$ & $(+)$ \\
\hline Assets &, & Current assets + fixed assets & $(+)$ \\
\hline
\end{tabular}

Operationalization of Variables: The definitions of the parameters in the model as well as their measurement, expectations and sources of data are stated in Table 1

Table 1 Definition of Variables and Sources of Data Employed in Regression Analysis

\section{DATA ANALYSIS AND INTERPRETATION}

Stationarity Test: From the stationarity tests results (Table 2), all the variables under consideration are characterized by first-order integration thus the panel estimations reveal a common unit root process. This further validates the suitability of our choice of estimation techniques since the theoretical built up is predicated on stationarity assumption. The stationarity test follows the Levin, Lin and Chu (which assumes homogeneity in the dynamics of the auto regression coefficients for all panel members); Im, Pesaran and Shins. Basically, the study adopts the Im, Pesaran and Shin as well as Levin, Lin and Chu unit root tests approaches. From the stationarity test results, all the parameters employed in this study were found to be stationary, although not at levels, but at first difference I(1). Thus, the variable defined in our dynamic panel modelling approach; GMM, are in line with the recommendation of Arellano and Bond (1991), Arellano and Bover (1995) and Blundell and Bond (1998), that variables of the GMM specifications must be stationary in their first difference. 
Panel Co-Integration Test: The co-integration result (Table 2) shows evidence of a co-integrating association among the variables in both models as reported by the significance of the Fisher statistics from Trace test as well as that from Max-Eigen test. Specifically, From the ROA equation, Trace test indicates 6 co-integrating equations at both $5 \%$ and $1 \%$ levels, while Max-eigen value test indicates 2 co-integrating equations at both $5 \%$ and $1 \%$ levels. Also, from the TOBINQ model, Trace test indicates 6 cointegrating equations at both $5 \%$ and $1 \%$ levels, while Max-eigen value test indicates 2 co-integrating equations at both $5 \%$ and $1 \%$ levels. The result indicates that the parameters used in the study are all significant at the conventional test levels as shown in Panel A and B of Table 2.

Table 2 Stationarity Test at First Difference- The Levin, Lin and Chu; Im, Pesaran and Shin Approach

\begin{tabular}{lcccccc}
\hline \multirow{2}{*}{ Variables } & \multicolumn{3}{c}{ Levin, Lin and Chu } & \multicolumn{3}{c}{ Im, Pesaran and Shin W-stat } \\
\cline { 2 - 6 } & \multicolumn{2}{c}{$\begin{array}{c}\text { Null Hypothesis: Unit root } \\
\text { assumes common unit root process) }\end{array}$} & \multicolumn{2}{c}{$\begin{array}{c}\text { Null Hypothesis: Unit root } \\
\text { (assumes individual unit root process) }\end{array}$} \\
\cline { 2 - 7 } & Stat & Prob & Remark & Stat & Prob & Remark \\
\hline AGE & -2.07 & $0.02^{* * *}$ & $\mathrm{I}(1)$ & -5.00 & $0.05^{* * *}$ & $\mathrm{I}(1)$ \\
BLOWN & -7.92 & $0.00^{* * *}$ & $\mathrm{I}(1)$ & -4.75 & $0.00^{* * * *}$ & $\mathrm{I}(1)$ \\
GOWN & -7.93 & $0.00^{* * *}$ & $\mathrm{I}(1)$ & -3.45 & $0.00^{* * * *}$ & $\mathrm{I}(1)$ \\
INOWN & -7.51 & $0.00^{* * * *}$ & $\mathrm{I}(1)$ & -4.54 & $0.00^{* * * *}$ & $\mathrm{I}(1)$ \\
ASSETS & -7.11 & $0.00^{* * *}$ & $\mathrm{I}(1)$ & -3.68 & $0.00^{* * * *}$ & $\mathrm{I}(1)$ \\
ROA & -16.70 & $0.00^{* * *}$ & $\mathrm{I}(1)$ & -8.15 & $0.00^{* * * *}$ & $\mathrm{I}(1)$ \\
TOBINQ & -19.44 & $0.00^{* * *}$ & $\mathrm{I}(1)$ & -9.16 & $0.00^{* * * *}$ & $\mathrm{I}(1)$ \\
\hline
\end{tabular}

NB: ${ }^{*}$ Significant at $10 \%,{ }^{* *}$ Significant at $5 \%,{ }^{* * *}$ Significant at $1 \%$.

Source: Authors' Computation, 2020

Table 3 Johansen-Fisher Co-Integration Test Results

\begin{tabular}{|c|c|c|c|c|c|c|c|}
\hline \multicolumn{8}{|c|}{ PANEL A: Fisher Statistics from Trace \& Max-Eigen Test Result for ROA Model Variables } \\
\hline Variables & $\begin{array}{l}\text { Hypothesized } \\
\text { No. of CE(s) }\end{array}$ & $\begin{array}{c}\text { Trace } \\
\text { Statistic }\end{array}$ & $\begin{array}{l}5 \% \text { Critical } \\
\text { Value }\end{array}$ & $\begin{array}{l}1 \% \text { Critical } \\
\text { Value }\end{array}$ & $\begin{array}{l}\text { Max-Eigen } \\
\text { statistic }\end{array}$ & $\begin{array}{l}5 \% \text { Critical } \\
\text { Value }\end{array}$ & $\begin{array}{c}1 \% \text { Critical } \\
\text { Value }\end{array}$ \\
\hline Series: & None & $183.69^{* *}$ & 94.15 & 103.18 & $60.62^{* *}$ & 39.37 & 45.10 \\
\hline AGE & At most 1 & $123.07^{* *}$ & 68.52 & 76.07 & $40.76^{* *}$ & 33.46 & 38.77 \\
\hline BLOWN & At most 2 & $82.31^{* *}$ & 47.21 & 54.46 & 25.49 & 27.07 & 32.24 \\
\hline GOWN & At most 3 & $56.82^{* *}$ & 29.68 & 35.65 & 22.39 & 20.97 & 25.52 \\
\hline INOWN & At most 4 & $34.43^{* *}$ & 15.41 & 20.04 & 19.15 & 14.07 & 18.63 \\
\hline $\begin{array}{l}\text { ASSETS } \\
\text { ROA }\end{array}$ & At most 5 & $15.28^{* *}$ & 3.76 & 6.65 & 15.28 & 3.76 & 6.65 \\
\hline \multicolumn{8}{|c|}{ PANEL B: Fisher Statistics from Trace \& Max-Eigen Test Result for TOBINQ Model Variables } \\
\hline Variables & $\begin{array}{l}\text { Hypothesized } \\
\text { No. of CE(s) }\end{array}$ & $\begin{array}{c}\text { Trace } \\
\text { Statistic }\end{array}$ & $\begin{array}{c}5 \% \text { Critical } \\
\text { Value }\end{array}$ & $\begin{array}{c}1 \% \text { Critical } \\
\text { Value }\end{array}$ & $\begin{array}{c}\text { Max-Eigen } \\
\text { statistic }\end{array}$ & $\begin{array}{c}5 \% \text { Critical } \\
\text { Value }\end{array}$ & $\begin{array}{c}1 \% \text { Critical } \\
\text { Value }\end{array}$ \\
\hline Series: & None & $168.72^{* *}$ & 94.15 & 103.18 & $48.47^{* *}$ & 39.37 & 45.10 \\
\hline AGE & At most 1 & $120.25^{* *}$ & 68.52 & 76.07 & $41.07^{* *}$ & 33.46 & 38.77 \\
\hline BLOWN & At most 2 & $79.18^{* *}$ & 47.21 & 54.46 & 24.23 & 27.07 & 32.24 \\
\hline GOWN & At most 3 & $54.96^{* * *}$ & 29.68 & 35.65 & 20.60 & 20.97 & 25.52 \\
\hline INOWN & At most 4 & $34.36^{* *}$ & 15.41 & 20.04 & 18.08 & 14.07 & 18.63 \\
\hline $\begin{array}{l}\text { ASSETS } \\
\text { TOBINQ }\end{array}$ & At most 5 & $16.28^{* *}$ & 3.76 & 6.65 & 16.28 & 3.76 & 6.65 \\
\hline
\end{tabular}

Source: Authors' Computation,2020 NB: $\left.{ }^{* * *}\right)$ denotes rejection of the hypothesis at the $5 \%(1 \%)$ level 


\section{Discussion of Findings and Policy Implication}

The panel estimation results for this study are reported in Table 4. The Hausman specification test reported in the lower segment of Table 4 fails to reject the randomeffects model in favor of the fixed effects model. The implication of the above finding is that some parameters may be fixed over time, but vary between countries, and others may be fixed among countries, but vary over time. The inference that can be derived from the Hausman specification test is that the Random-effects model is favored to the Fixedeffects model for the levels regression estimates for the ROA model. On the other hand, the result from the traditional panel estimation for TOBINQ model as reported in Table 5 rejects the random-effects model in preference for the fixed effects model.

Also, results of the dynamic model for ROA are presented in the second part of the Table 4, while results of the dynamic model for Tobin's Q are reported in the first part of the Table 5 respectively. The outputs from the second-order serial correlation test for both equations (from the Arellano-Bond test) indicate that residuals from the dynamic panel equation are not serially correlated. This further implies that the instrumental variables employed in estimation are valid and unbiased. The p-value of the Sargan test is judiciously large for both models. Thus, we fail to reject the null hypothesis at $1 \%$ level, that the set of instruments we used in GMM for both the ROA and TOBINQ models are correctly specified. Hence, that there are no problems of misspecification with the set of instruments incorporated into our GMM identity. In addition, all the series incorporated into the dynamic panel model are utilized at first difference, and this follows the prescription of Arellano and Bond (1991).

From the results in Table 4, the coefficient of one-period lagged value of ROA was positive and significant statistically at $1 \%$ in the dynamic panel model and is in consonance with our a priori expectation (similar to the result of TOBIN Q in Table 5). Precisely, the outcome reveals that a unit increase in the TOBIN Q of Sub-Sahara African countries in the previous year will lead to a corresponding increase in firm profitability (proxies by ROA and Tobin's Q) of the entire region in the current year by 0.18 unit. The implication of the above findings is that previous year performance has the tendency to positively influence both current and future performance behavior of the manufacturing sector in Sub-Sahara Africa. This suggests that the impact of the previous shocks in financial performances among manufacturing firms in Sub-Sahara African countries create positive spill-over effects, which translate into present circumstances and future opportunities of the region.

In addition, the coefficient of Government ownership concentration was positive in the random and fixed effects models, the GMM model from the TOBIN Q equation as well as the fixed effects model from the ROA equation. This finding further substantiates earlier findings of Netter \& Megginson (2001) and Boubakri \& Cosset (2005) who argue that government owned firms are advantaged as the government can allocate capital to them for investment to prompt financial and economic development, mostly for nations that have economic institutions that are underdeveloped and are undertaking government funds for projects with social benefits. Ongore and K'Obonyo (2011), Mrad and Hallara (2012) and Munisi \& Randy (2013) further posit that, government retains some ownership in privatized firms to boost shareholder confidence, investment protection and managerial monitoring.

It however turned adverse in the case of random effects model as well as the GMM Panel Data Estimation Results from ROA Model. This further confirms previous findings of Ongore and K'Obonyo (2011), Mishari (2012), Alulamusi (2013) and Mutisya (2015) 
who observe that government ownership is inefficient, characterized by bureaucratic bottlenecks and the ownership rights of government firms do not have clear incentives to improve firm performance.

Also, the coefficient of the two-period lagged value of Government ownership concentration was positive in all panel estimation results from the ROA model. Though, it was only significant at $1 \%$ level in the fixed effects model. Furthermore, the coefficient of Block Ownership concentration was negative in the ROA random effects and dynamic panel models, while it was found to be positive in all estimations for the Tobin's Q model as well as the ROA fixed effects model. In addition, it was statistically relevant at $1 \%$ level in estimating both the ROA and Tobin's Q fixed effects models as well as the dynamic panel model for Tobin's Q relations, while it only became significant statistically at $10 \%$ level in the ROA dynamic panel model and Tobin's Q random effects model, respectively. Our results on the positive impacts of Block ownership concentration on firm's profitability further conform to previous findings of Holderness and Sheehan (1988), Morck etal (1988), Wruck (1989), Gorton and Schmid (1996), and Shleifer and Vishny (1997) who emphasize that a high acquisition of equity tends to create more pressure on agents to behave in certain ways. Similarly, the coefficient of one-period lagged value of Block ownership concentration was positive in both random effects and panel estimation results from the ROA model, while it was found to be negative in all estimations for the Tobin's Q model as well as the ROA fixed effects model. It was statistically significant at $1 \%$ level in both the ROA fixed effects model and the dynamic panel estimations from the Tobin's Q model respectively. Likewise, the coefficient of the two-period lagged value of Block ownership concentration, though, only significant at $1 \%$ in the fixed effects model, was negative in all panel estimation results from the ROA model. In addition, the coefficient of Institutional Ownership acquisition was positive in the ROA random effects and dynamic panel models. This is in line with previous findings of Rhoades (2000); Elyasiani and Jia (2010); Mishari (2012); Gayan and Ishari (2016) who believe that supervision by institutional shareholders is mostly to lead to improved company profitability because, as sophisticated and major investors, institutional shareholders have the strength and expertise to supervise organization at low cost, and capability to wield enough authority to change the control formation and the firms path of operations. However, it was found to be negative in all estimations for the Tobin's Q model as well as the ROA fixed effects model respectively. Interestingly, it was statistically significant at $1 \%$ level in the ROA fixed effects model as well as the Tobin's Q fixed effects and GMM models respectively. Although, it only attained statistical significance at 10\% level in the ROA GMM and Tobin's $\mathrm{Q}$ random effects models respectively. In the same way, the coefficient of one-period lagged value of Institutional ownership concentration was negative in both random effects and panel estimation results from the ROA model, while it was found to be positive in all estimations for the Tobin's Q model as well as the ROA fixed effects model. Also, it was statistically significant at $5 \%$ level in the determination of profitability of the selected manufacturing that are value-optimizing companies in the Sub-Sahara Africa region from the dynamic panel estimation result for TOBINQ Model and 10\% level in both ROA and Tobin's Q fixed effects models. A positive coefficient ensued in all panel estimations for the ROA model in the case of the association between manufacturing performance and two-period lagged value of Institutional ownership concentration. However, this was only significant at $1 \%$ level in the ROA fixed effects model. 
Table 4 Panel Data Estimation Results for ROA Model (Sub-Sahara Africa)

\begin{tabular}{|c|c|c|c|c|c|c|c|c|c|}
\hline \multirow{2}{*}{ Variables } & \multicolumn{3}{|c|}{ Random Effect Model } & \multicolumn{3}{|c|}{ Fixed Effect Model } & \multicolumn{3}{|c|}{ Panel GMM Model } \\
\hline & Coeff & t-stats & Prob & Coeff & t-stats & Prob & Coeff & t-stat & Prob \\
\hline $\mathrm{C}$ & 3.68 & 0.88 & 0.38 & 16.6 & 8.40 & $0.00^{* * *}$ & - & - & - \\
\hline $\operatorname{ROA}(-1)$ & - & - & - & - & - & - & 0.21 & 3.85 & $0.00^{* * *}$ \\
\hline GOWN & -3.26 & -9.13 & $0.00^{* * *}$ & 0.04 & 0.73 & 0.47 & -2.91 & -7.00 & $0.00^{* * *}$ \\
\hline GOWN(-1) & 2.33 & 3.99 & $0.00^{* * * *}$ & -0.29 & -3.88 & $0.00^{* * *}$ & 1.28 & 1.88 & $0.06^{*}$ \\
\hline GOWN(-2) & 0.77 & 1.42 & 0.16 & 0.15 & 2.68 & $0.01^{* * *}$ & 0.37 & 0.60 & 0.55 \\
\hline BLOWN & -0.61 & -1.36 & 0.17 & 0.35 & 4.90 & $0.00^{* * *}$ & -0.53 & -1.64 & $0.10^{*}$ \\
\hline BLOWN(-1) & 0.45 & 0.72 & 0.47 & -0.20 & -2.69 & $0.01^{* * *}$ & 0.55 & 1.46 & 0.15 \\
\hline BLOWN(-2) & -0.21 & -0.42 & 0.67 & -0.21 & -4.02 & $0.00^{* * *}$ & -0.35 & -1.35 & 0.18 \\
\hline INOWN & 0.60 & 1.26 & 0.21 & -0.36 & -4.83 & $0.00^{* * *}$ & 0.60 & 1.80 & $0.07^{*}$ \\
\hline INOWN(-1) & -0.48 & -0.72 & 0.47 & 0.15 & 1.79 & $0.07^{*}$ & -0.67 & -1.58 & 0.12 \\
\hline INOWN(-2) & 0.29 & 0.54 & 0.59 & 0.29 & 5.48 & $0.00^{* * *}$ & 0.34 & 1.07 & 0.29 \\
\hline ASSETS & 0.00 & 0.83 & 0.41 & 0.002 & 3.53 & $0.00^{* * *}$ & 0.002 & 3.33 & $0.00^{* * *}$ \\
\hline AGE & -0.01 & -0.09 & 0.93 & -0.47 & -6.69 & $0.00^{\text {*** }}$ & -0.38 & -2.75 & $0.01^{* * *}$ \\
\hline \multicolumn{2}{|c|}{ No. of Observation } & \multicolumn{2}{|l|}{239} & \multicolumn{3}{|c|}{239} & \multicolumn{3}{|c|}{209} \\
\hline R-Square & \multicolumn{3}{|c|}{0.27} & \multicolumn{3}{|c|}{0.76} & & & \\
\hline Adjusted R-Square & \multicolumn{3}{|c|}{0.23} & \multicolumn{3}{|c|}{0.71} & & & \\
\hline F-Statistics (p & 7.55 & $.00)^{* * *}$ & & \multicolumn{2}{|c|}{$15.77(0.00)^{* * *}$} & & & & \\
\hline Hausman Tes & \multicolumn{5}{|c|}{$\mathrm{Chi}^{\wedge} 2(11)=21.10(0.0323)$} & & & & \\
\hline Sargan Test & \multicolumn{5}{|c|}{$\mathrm{Chi}^{\wedge} 2(12)=16.514(0.16)$} & & & & \\
\hline \multicolumn{4}{|c|}{ Test for Second Order Autocorrelation } & \multicolumn{3}{|c|}{$Z=0.5998(0.549)$} & & & \\
\hline
\end{tabular}

NB: *Significant at $10 \%,{ }^{* *}$ Significant at 5\%, ${ }^{* * *}$ Significant at $1 \%$. (Author Comp.2020)

Table 5 Panel Data Estimation Results for TOBINQ Model

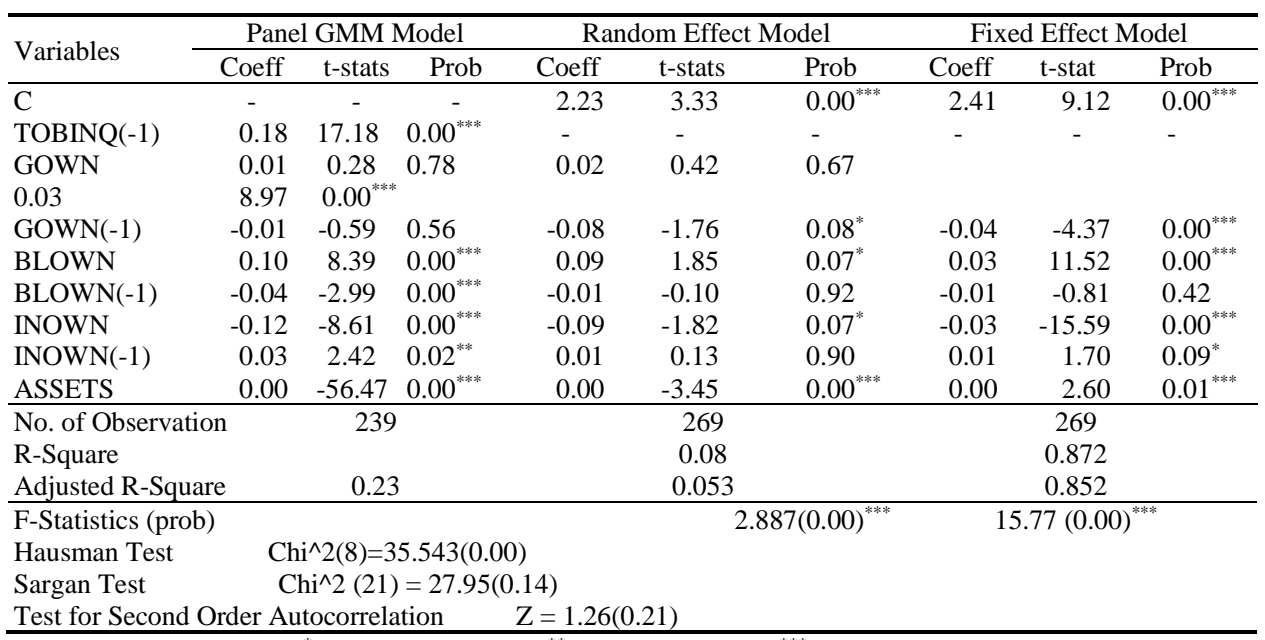

NB: ${ }^{*}$ Significant at $10 \%,{ }^{* *}$ Significant at $5 \%,{ }^{* * *}$ Significant at $1 \%$

Source: Authors' Computation, 2019

\section{FINDINGS AND CONCLUSION}

The results obtained in the empirical analysis of this study were found to be robust to both specification and data interpretation. The general outcome implies that rights acquisition essentially has huge influence on performance of manufacturing firms. More specifically, 
both government and block ownership structures have a huge negative effect on performance of manufacturing firms in Sub-Sahara Africa countries while institutional rights ownership has a significant direct effect on performance of manufacturing companies in Sub-Sahara Africa countries. However, based on market base measurement (Tobin Q) model, both government and block ownership structure have significant direct effect on the performance of manufacturing firms in Sub-Sahara Africa countries. Institutional ownership concentration however has a significant negative effect on profitability of manufacturing firms in Sub-Sahara Africa countries. Total Assets has a significant positive impact on performance of manufacturing companies in Sub-Sahara Africa countries. Firm's Age has an adverse significant effect on profitability of manufacturing companies in Sub-Sahara Africa countries. It is worthy to note that on the basis of comparison between the two indicators of profitability of manufacturing firms in SSA countries, the market base valuation model is a better measure based on the findings above. This finding is mostly important because it has shown that there is no one best financial performance measurement at all time, the uniqueness of the situation will enable corporate managers of manufacturing firms to know the best performance measurement variable to adopt when analyzing their firm performance in relation to ownership structure.

\section{CONCLUSION}

This study investigates the effect of ownership structure on the financial performance of listed manufacturing firms in three Sub-Saharan Africa countries (Nigeria, Kenya and South-Africa) using the system Generalized Method of Moment (GMM) technique of data analysis. Generally, our findings show that there was a robust relationship among rights acquisition and profitability of listed manufacturing firms sub-Sahara Africa. Therefore, it can be concluded that different ownership structures were statistically significant in influencing the performance of manufacturing companies quoted in the respective bourses of selected Sub-Sahara Africa economies this conclusion corroborates the conclusion of Alabdullah (2018), Feldman et al (2019) and Dakhlallh et al (2019) whose respective studies also conclude that ownership structures significantly influence the performance of firms, but contradict Paniagua et al (2018) whose study concludes that ownership structure has negative relationship with profitability ratio. Ownership structure of manufacturing firms has been embraced by most firms and has taken center stage of most economies in the world. This is so because it helps in building an efficient and robust corporate governance which can enhance performance of the individual manufacturing firm and lead to the overall growth of the various national economies. In order to gain extensively from the benefits of an effective corporate governance mechanism, regulatory agencies of SSA countries should put in place different institutional reforms that will help in carrying out operational activities within the SSA region with little or no stringent rules that can help manufacturing firm operate efficiently.

This study contributes to extant literatures by employing the system GMM technique which provides a framework within which the relationship between ownership structure and financial performance were considered. Besides, the study also compares the impact of different ownership structures on different measures of financial performance thereby revealing which type of structure has the most significant influence on which performance measure especially when considering manufacturing firms in SSA context. 
This study being an aggregate cross-country study encountered the limitation of heterogeneity in data collection and measurement. This problem arose because of the different data computational techniques across the SSA countries, however, the system GMM estimator was able to produce less bias and more precise data estimate.

\section{RECOMMENDATIONS}

The results from the empirical analysis provide strong background and inferences for certain policy and practical recommendations for practitioners and policy makers. In the first place, the study shows that a long run correlation occurs among ownership concentration and profitability among the manufacturing firms in SSA region. Thus firms need to consider corporate governance as a long run strategy for promoting growth and other forms of expansions. Since the study has shown that the impact of rights acquisition differs on the basis of possession dimension, there is need for investors to consider the area of interest before engaging in investment. The regulatory agencies within each of the countries in the region should also consider providing enabling environment for encouraging intra-regional integration for manufacturing firms to enhance operational activities.

The future direction of research in this study is dynamic in the context that there is need to consider the influence of dispersed ownership together with ownership structure with regards to the effect of both forms of ownership on firm performance. Besides, financial sector development indices may also be included in future studies models. Also econometrically, further study can use non-linear (as different from linear equation adopted in this study) single equation model to test the relationship between ownership structure and financial performance of manufacturing firms.

\section{REFERENCES}

Adebiyi, A.J., \& Kajola, S.O. (2011). Ownership structure and firm performance: evidence from Nigerian listed companies. Corporate Ownership \& Control, 8(4), 25 - 45.

Alabdullah, T.T.Y. (2018). The relationship between ownership structure and firm performance: Evidence from Jordan. Benchmarking: An International Journal 25(1), 319-333.

Alulamasi, F. (2013). The examination of the effect of ownership structure on firm performance in listed firms of Tehran stock exchange. Journal of Business Management, 6(3), 249-266.

Arellano, M., \& Bover, O. (1995). Another look at the instrumental variable estimation of error component models. Journal of Econometrics, 68, 29-51.

Arellano, M., \& Bond S. (1991). Some tests of specification for panel data: Monte Carlo evidence and an application to employment equation. Review of Economic Studies, 58, 277-297.

Benjamin, B., \& Dirk, C. (2015). Ownership concentration, institutional development and firm performance in central and eastern Europe. Managerial and Decision Economics journal, 2(1), 119-124.

Berghe, V., \& Levrau, L. (2007). Corporate governance and board effectiveness: beyond formalism. Working papers of Faculty of Economics and Business Administration, Ghent University, Belgium.

Berle, A., \& Means, G. (1932). The modern corporation and private property. New York: The Macmillan Company.

Boubakri, N., \& Cosset, J. (2005). Does Privatization Meet the Expectations? Evidence from African Countries. Retrieved from: www.ssrn.com/abstract, accessed on 17 August 2019.

Brown, J. (2004). Statistics Corner. The cronbach alpha reliability estimates. Retrieved from: http;//www.jact.org/ test/bro_9.htm, accessed on 15 August 2019

Dakhlallh, M. M., Rashid, N. M., Abdullah, W. A. W., \& Dakhlallh, A. M. (2019). The effect of ownership structure on firm performance among Jordanian public shareholders' companies: Board independence as a moderating variable. International Journal of Academic Research in Progressive Education and Development, 8(3), 13-31. 
Elyasiani, E., \& Jia, J. (2010). Distribution of institutional ownership and corporate firm performance. Journal of Banking \& Finance, 34(3), 606-620.

Feldman, E. R., Amit, R., \& Villalonga, B. (2019). Family firms and the stock market performance of acquisitions and divestitures. Strategic Management Journal 40(5), 757-780

Friedman, M. (1953). The methodology of positive economics. In essays in positive economics. Chicago: Chicago University Press.

Garcia, M. E., \& Sanchez, B. J. P. (2011). Ownership structure and the cost of debt. European Accounting Review, $15,1-28$.

Gayan, M. A., \& Ishari, S. (2016). Impact of ownership structure on firms' performance of manufacturing companies in Sri Lanka. International Journal of Scientific and Research Publications, 6(10), 2250-3153.

Gonzalez, F., \& Molina, K. (2010). Bank regulation and risk-taking incentives: An international comparison of bank risk. Journal of Banking and Finance, 29(5), 1153-1184.

Gorton, G., \& Schmid, F. (1996). Universal banking and performance of German firms. Working paper 5453, National Bureau of Economic Research, Cambridge, Massachusetts USA.

Holderness, C. G., \& Sheehan, D. P. (1988). The role of majority shareholders in publicly held corporations: An exploratory analysis. Journal of Financial Economics, 20(2), 317-346.

Jensen, H. (1989). Toward a stewardship theory of management. The Academy of Management Review, 20-47.

Jiang, P. (2015). The relationship between ownership structure and firm performance: an empirical analysis over Heilongjiang listed companies. Nature and Science, 2(4),87-90

JSE (2018). Johannesburg Stock Exchange Facts Book. Retrieved from: www. JSE.Co. Za

Kao, M., Hodgkinson, L., \& Jaafar, A. (2018). Ownership structure, the board of directors and firm performance: Evidence from Taiwan. Corporate Governance 19(1), 189-216.

Lins, K. (2002). Equity Ownership and Firm Value in Emerging Markets. Working paper, Utah: University of Utah.

Madhani, P. M. (2016). Ownership concentration, corporate governance and disclosure practices: A study of firms listed in Bombay stock exchange. The IUP Journal of Corporate Governance, 15(4), 7-36.

Maina, L. (2014). Capital structure and firms performance in kenya: evidence from firms listed at the Nairobi securities exchange. International Journal of Social Sciences and Entrepreneurship, 1(11), 1-14.

Malik, H. (2011). Determinants of insurance companies' profitability: an analysis of insurance sector of Pakistan. Academic Research International, 1(3), 2223-2253.

Mishari, A. (2012). The influence of institutional and government ownership on firm performance: evidence from Kuwait. International Business Research Journal, 5(10), 192-200.

Monsen, R. J., Chiu, J. S., \& Cooley, D. E. (1968). The effect of separation of ownership and control on the performance of the large farm. The Quarterly Journal of Economics, 82(3), 435-451.

Morck, R., Shleifer, A., \& Vishny, R. W. (1988). Management ownership and market valuation: An empirical analysis. Journal of Financial Economics, 20, 293-315.

Mrad, M., \& Hallara, S. (2012). The impact of residual government ownership on performance and value creation: The case of privatized French companies. Procedia Soc. Behav. Sci. 62, 473-488.

Mudi, O. L. (2017). Ownership structure and financial performance of firms listed at the Nairobi Securities Exchange. A thesis submitted in partial fulfilment for the degree of master of business administration (finance) University of Nairobi.

Mugobo, V. V., Mutize, M., \& Aspeling, J. (2016). The ownership structure effect on firm performance in South Africa. Corporate ownership \& Control, 13(2), 462-465.

Munisi, G., \& Randy, T. (2013). Corporate governance and company performance across Sub-Saharan African countries. Journal of Economics and Business, 70(C), 92-110.

Mutisya, B. (2015). The relationship between ownership structure and financial performance of companies listed at the Nairobi securities exchange. Unpublished MBA thesis, Nairobi: University of Nairobi.

Nahila, N., \& Amarjeet, K. (2016). The effect of ownership structure on firm profitability in India. International Journal of Economics and Finance, 8(6).

Nairobi Stock Exchange (2018). Handbook on profiles and performance of listed Companies. (2006-2017). Nairobi: NSE. Retrieved from: http://www.hisanetafrica.com/nse.php

Nigeria Stock Exchange (2018) NSE Fact Books. Retrieved from: www. nse.com.ng

Netter, J., \& Megginson, W. (2001). From state to market: a survey of empirical studies on privatization. Journal of Economic Literature, 39(2), 321-389.

Ongore, O., \& K'Obonyo, O. P. (2011). Implications of firm ownership identity and managerial discretion on financial performance: empirical evidence from Nairobi stock exchange. International Journal of Humanities and Social Science, 13(1), 136-156.

Paniagua, J., Rivelles, R., \& Sapena, J. (2018). Corporate governance and financial performance:The role of ownership and board structure. Journal of Business Research 89, 229-234 
Sadiq, M., Othman, Z., \& Ooi, C. K. (2019). A study of interaction effects of political influences and earning management on organizational performance. Asian Economics and Financial Review, 9(5), 642-650.

Santamaria, M., \& Azofra, V. (2011). Ownership, control and pyramids in Spanish commercial banks. Journal of Banking \& Finance, 35(6), 1464-1476.

Saunders, A., Strick, E., \& Travlos, G. (2000). Ownership structure, deregulation, and bank risk taking. Journal of Finance, 45(2), 643-654.

Shleifer, A., \& Vishny, R. W. (1997). A survey of corporate governance. Journal of Finance, 52(2), 737-783.

Trien, L., \& Chizema, A. (2011). State ownership and firm performance: evidence from the Chinese listed firms. Organization of Marketing of Emerging Economies, 2,72-90.

Villalonga, B., \& Amit, R. (2006). How do family ownership, control, and management affect firm value? Journal of Financial Economics, 80(2), 385-417.

Wanjiku, P. K. (2015). The effect of ownership structure on the financial performance of firms listed at the Nairobi securities exchange. Retrieved from: http://erepository.uonbi.ac.ke/bitstream/handle/11295/93458/ Wanjiku_The $\% 20$ effect $\% 20$ of $\% 20$ ownership $\% 20$ structure $\% 20$ on $\% 20$ the $\% 20$ financial\%20performance $\% 2$ 0 of\%20firms.pdf?isAllowed $=y \&$ sequence $=3$

\section{VLASNIČKA STRUKTURA I FINANSIJSKE PERFORMANSE PROIZVODNIH KOMPANIJA U PODSAHARSKOJ AFRICI}

Ovaj rad istražuje uticaj vlasničke structure na finansijske performanse navedenih proizvodnih kompanija u tri podsaharske zemlje (Kenija, Nigerija, Južnoafrička Republika) na osnovu indeksa kritilčne mase na njihovim orgovarajućim berzama. Relevantni podaci iz finansijskih izveštaja uzrokovanih firmi su analizirani uz pomoć ko-integracionog testa i GMM sistema za period 20102019 korišćenjem ROA i Tobin-Q kao zavisne varijabile dok su objašnjenja varijabile bila državno vasništvo, zajedničko vlasništvo i institucionalno vlasnišstvo. Empirijski rezultati su otkrili da sve objašnjavajuće varijabile imaju značajnog uticaja na indikatore performansi (ROA, TOBIN Q). Rezultati provere robusnosti su takođe otkrili da koncentracije i državnog i institucionalnog vlasništva imaju dominantno negativni uticaj na finansijske performanse navedenih zemalja dok je koncentracija blok vlasništva u velikoj meri pozitivna za većinu proizvodnih kompanija. Studija preporučuje donosiocima odluka da stvore povoljne politike koje bi ohrabrile balansirano insvestiranje od strane svih kategorija investitora i obezbede da samo onih nekoliko vlasnika koji imaju neophodna stredstva da diverzifikuju i privuku veštine i kompetrencije poboljšaju performanse preduzeća. Vlada takođe treba da zadrži neki udeo u vlasnišstvu domaćih i stranih firmi da bi povećala poverenje akcionara.

Ključne reči: vlasnička struktura, proizvodne kompanije, performanse, GMM 